\title{
THE IMPLEMENTATION OF TASK BASED LEARNING IN TEACHING WRITING DESCRIPTIVE TEXT TO THE JUNIOR HIGH SCHOOL
}

\author{
Achmad Saifudin ${ }^{1}$ \\ Universitas Negeri Surabaya \\ Slamet Setiawan ${ }^{2}$ \\ Universitas Negeri Surabaya \\ Syafi'ul Anam ${ }^{3}$ \\ Universitas Negeri Surabaya \\ $\underline{\text { achmadboy74@gmail.com }}{ }^{1}$
}

Submit, 04-07-2020 Accepted, 22-12-2020 Publish, 28-12-2020

\begin{abstract}
The research aims at investigating the implementation of task based learning conducted by the teacher in teaching writing descriptive text for junior high shool students of seven grade.The student still have problem in writing especially descriptive text. The study examine show to the teacher conducs the task based learning in teaching writing trought some step and elaborates students' ability in writing descriptive text.the research used qualitative approach because the result of the data analyzed was in descriptive phenomenom such a word, sentence and utterence. The data is collected from observation, interview and students' writing. The analysis of the data was conducted thought categorization, data display and drawing conclusion. The subjects of this research are an english teacher and his students of VII grade. The result of the study indicates that the implementation of task based has many weaknesses in some aspects. The consuming time in doing the task is one of the matters. Students' use of mother tongue instead of the target language makes the implementation of task based learning does not go as expected.In reference to the findings of the study, some suggestion proposed. The english teacher should use and design task which will not consume more time,so the step in task based learning will bwe accommodated in a meeting. The student should speak in the target language and the task based learning is implemented in order to reach the aim of this approach.
\end{abstract}

Key Words : Task - Based Learning, Descriptive text, Students' writing 


\section{INTRODUCTION}

English is an International language and the first foreign language taught in Indonesia. It becomes one of the compulsory subjects that must be learnt by students of junior high school. English is used not only for communication but also for skill that has to be mastered to face the high competition in the global era. Due to the important role of English in the global era, approaches, methods, and techniques of teaching English are developed. The objective of using techniques is to enable students to learn and practice English easily. According to the competence-based curriculum, the objective of learning English in senior high school is to enable students to communicate in English. The communication skill is reached through the development of the four major skills speaking, listening, reading, and writing.

The teacher has a role to set the plan of drafting students ${ }^{\text {ee }}$ learning goals. Teacher will implement the effective instruction about what he/she has planned. She must be able to describe exactly what students will learn, how well they will learn it and what they will do to demonstrate that learning. The administrators have also some responsibility in this cooperation. The administrators refer to the principal and the stake holder which should recognize what does and does not work to promote learning and achievement for all students. They make sure that learning goals made by the teacher have been set up based on the students ${ }^{\text {ee }}$ performance data

On the other hand, thr government also gives a hand to accommodate the teaching and learning process to be successfu with 2013 curriculum. Based on Permendiknas no 103 (2014), this curriculum expects learners to be active and creative. It is believed that the process of learning should emphasize more on learners, it is called students centered leaning. By students centered hopefully the students are able to explore their ability in the four language skills they should master. Teachers do not become the giver knowledge or the controller, even the authority (Harmer, 2004). Students by themselves look for the knowledge from as many resources as they could find. The teachers act as tutors and resources; they help students when they are stuck having no ideas to answer. When students are having small groups ${ }^{\text {ee }}$ discussion, teacher guide and monitor them. Even when students have to do the task individually, teacher helps them if only the students are asking for a help.

Writing plays an important role in human life since it enables us to communicate with others especially those who are not present. Moreover, one can use writing to express ideas, feeling, thought and share them with others. Beside its function as a means of communication, one can create meaning from his or her intellectual resources and activities. As Brown, (2007) states, writing is considered as the difficult skill to master since it involves several components 
which need to be employed i.e the content, organization, vocabulary,language use and punctuation.

Descriptive Text is a kind of text with a purpose to give information. The context of this kind of text is the description of particular thing, animal, person, or others, for instance: our pets or a person we know well. It differs from Report which only describes things more general and Descriptive describes things more spicific and detail. They have to able to make outline of their writing, to following paragraphs. Beside, they must pay attention to the merchanics of writing (spelling, punctuation, and capitalization ), word choice, grammar and the aability to connect sentences to become a unified thought in written discourse.

There are some previous study that argue and suggest applying task based learning, Syahputra, (2013) give suggestion that first, the teacher should choose the technique and materials that are appropriate with the students' needs and levels so that the interesting. Then, the teacher should give short, clear and simple instruction; the teacher should keep in control the students activities. Adk, (2015) argues that Problem Based Learning did make the students interest and gave more attention to learn descriptive tex But the reseacher suggest to find new learning / strategy to improve writing descriptive text. Siahaan, (2013) held a survey on An analysis of students' ability and difficulties in writing descriptive texts in indonesia. States that that the students representing the middle and high achievers had a good control about the schematic structure of descriptive text. They also were able to use appropriate linguistic features.

On the other hand, it was also revealed that the low achievers were still confused in identifying the schematic structure of descriptive text. Aksu, (2015) found throughout the study, students' written work which are essays written every other week, have been analyzed to examine the extent of their critical writing skills. He suggest that taking the importance of critical thinking an writing for our teachers into account, there is necessity for a course on " critical Reading and writing " in the curriculum of ELT departments (Kuswoyo \& Hum, 2017). In their research about Improving Student Listening Skill Using Task- Based Approach in EFL, He suggest that the researcher can use Task - Based Approach not only listening but also writing and speaking. Carless, (2007) suggests a weak version of task-based teaching is likely to be most suitable for schooling and reinforces claims for the desirability of context-sensitive approaches. Tan, (2016) states that a contextual adaptation to TBLT in Chinese EFL setting should be made and TBLT can be best feasible and useful if a context-sensitive TBLT approach in which Chinese traditional values, examination demands, teachers' teaching beliefs and practices interact best with the principles of TBLT. The last Butler, (2018) state potential options for moving forward, including (a) employing more contextually feasible and flexible interpretations of CLT and TBLT, (b) 
implementing decentralized or innovative language-in-education policies, and (c) creating communities of learning outside of the classroom as well as in the classroom Communicative.

In the classroom context, teachers have many challenges in facilitating the students learning English. Consequently, the teachers need to think how to make the students be easier to get knowledge and implement it. To facilitate their students in achieving the goals of the learning, they need to think a set of approach or method as well, to be done. This approach, called Task-based Learning, is in line with the instruction existed in the Peraturan Pemerintah No 32 2013 which mentions in verse 19 that the learning process should be conducted interactively, inspiringly, fun, challenging and motivate the learners to be active participate in it, also give them a spacious part for their creativity and independency based on the talents, physically and psychologically growth. Moreover, the learning design has altered in some ways; that it is instructed to be student centered, that mostly students take part in whole session which allow teacher to guide and monitor them, and also group session in doing the assignment. Therefore, Task-based Learning will match with the instruction and help the learning process go smoothly. This approach is students centered, teacher doesn ${ }^{\text {ee }}$ play most roles. They are in groups while doing the assignment and moreover the target language is always used to create communicative language environment.

Base on the condition, the researcher will implement the Task - based learning in the teaching writing for junior high school students, which had become a burden for a teacher in MTS Sunan Kalijaga to teach, and so the students are hard to learn it. The researcher also investigated whether there was any modification in the implementation of tasjk based learning in teaching english writing have impacted on students' writing product in the contex of curiculum.

\section{LITERATURE REVIEW}

\section{Definition of Writing}

Many experts give different definitions about writing. According to Hamilton, (1988), writing is a communicative act, a way of sharing observation, thoughts or ideas with others and ourselves. Writing is far from being a simple. It is more complicated than it seems at first, and often seems, to be the hardest skill. Writing means to try producing or reproducing writing message.

With regard to the writing skill Oshima, A., \& Hogue, (1999) states that, before we write, we need to determine what to write, because writing is not just constructing words to be a good sentence, but the writer should know well the message that will be delivered to the readers. Writing is not such 
a complex process but it can lead to learner frustration, because to write, it take times and energy it needs more ideas, feelings and experiences as creative act which requires time and positive feedback to be done well.

In term of skills, producing a coherent, fluent, extended piece of writing is probably the most difficult thing to do in language. Learning to write in either a first or second language is one of the most difficult tasks a learner encounters. Many native speakers leave school with a poor command of writing. Learning to write is not just a question on developing a set of mechanichal"'orthographic skill". It also involves learning a new set of cognitive and social relation.

In writing students have to include many things that are used as criteria. A good deal of attention is placed on model compositions that students would emulate and how well a students product measured up against a list of criteria that included content, organization, vocabulary use, grammatical use, and mechanical consideration such as spelling and punctuation. In line with that statement, Harmer, (2007) explains that writing requires many devices such as grammatical skill, stylistic skill and judgment skill Kinds of Reading.

\section{Importance of Writing}

Writing is very interesting. Many people have to know the importance of writing. It might be called as a recreational aspect of writing. It can be said that writing can give both emotional and aesthetic pleasure.

According to Oshima, A., \& Hogue, (1999), the good writing should be not only effective but also aesthetically sound. In other words, writing is a way to express someone's feeling, although, there is not denying that writing is often considered as the hardest skill to be acquired for many people. They want to express their feeling, thoughts and experiences, but they get difficulties finding out precise words to reveal their feeling.

In accordance with the statements above, Heaton, (1975), says that the importance of writing in teaching and learning is as follows: Writing helps the students. How? First, writing reinforces the grammatical structure, idioms, and vocabulary that we have been teaching our students. Second, when the students write, they also have a chance to adventurous with the language to go beyond what they have learned to say, to take risk. Third, when they write, they necessarily become very involved with the new language and to express ideas and the constant use of Eye, hand, and brain is unique way to reinforce learning.

Having ability to write well is really important because it is not only for expressing someone's feeling but can also be used to increase their opportunities for career promotion. 


\section{Writing Assesment}

Assesment of wrriting is a legitimate undertaking. But, it is a complex task,involving two competing tendencies. First the impulse to measure writing as a general construct, and second, the impulse to measure writing as a contextualized. Site - and genre - specific ability (Hamilton, 1988).

Writing asessment can serve to inform both the individual and the public about the achievement of the students and the effectiveness of teaching. On the other hand, it can be enourmousely harmful because of the power of language personally for our students as learners since learning is mediated through language.

Writing asessment that a line notes students from writing is counterproducting take an accurate on valid measure of their writing even more so. But writing assesment that encourages students to improve the facility with the written word, to appreciate their power with that word and the responsibilities that accompany such power, and that salutes students achievements as well as guides them, should serve as acrucially important educational force.

\section{Descriptive Text}

Descriptive Text is a kind of text with a purpose to give information. The context of this kind of text is the description of particular thing, animal, person, or others, for instance: our pets or a person we know well. It differs from Report which describes things, animals, persons, or others in general. The Social Function of Descriptive Text is to describe a particular person, place, or thing. (Gerot',1994).

\section{The Language Feature of Descriptive Text}

The descriptive text has generic structures which distinguish this text from the others. First, it involves identification. The second is description. Description refers to the description of the things or a person in terms of parts, characteristics, and qualifications. The tense used in writing descriptive is simple present tense.

Table 1 The Table of Descriptive

\section{Identification}

It is the identification part where a particular person, animal, or thing to describe is introduced.

\section{Description}

It is the focus of the text in which the person, animal, or thing is described in terms of parts, characteristics, or qualification. 
Descriptive often uses 'be' and 'have'. Tense which is often used is simple present tense. However, some times it uses past tense if the thing to be described doesn't exist anymore. Significant grammatical features of descriptive text are :

1. Focus on specific participants (My English teacher, Andini's cat, My favourite place)

2. Use of Simple Present Tense.

3. Use of Simple Past Tense if Extinct.

4. Verbs of being and having 'Relational Processes'. (My mum is really cool, She has long black hair)

5. Use of descriptive adjectives (strong legs, white fangs)

6. Use of detailed Noun Phrase to give information about the subject. (a very beautiful scenery, a sweet young lady, very thick fur)

7. Use of action verbs 'Material Processes' (It eats grass, It runs fast)

8. Use of adverbials to give additional information about behaviour (fast, at tree house)

9. Use of Figurative language (John is as white as chalk.)

\section{Task-based Learning}

Task-Based learning is an approach which aims at creating opportunities for language learning and skill-development through collaborative knowledgebuilding. Through some tasks the students ought to use the target language for a communicative purpose in order to achieve an outcome. The tasks used in this approach interpret the real world, so students sense factual situation in using the target language. It intends to make the students focus on meaning by processing and accomplishing the tasks given. The students do tasks in small groups and practice using language necessary for doing the particular task. Its focus is on task completion and therefore students are free to use whatever language they have at their disposal to achieve this. Through the steps in Taskbased Learning the teacher focuses on the students, how they explore their target language by increasing the students ${ }^{\text {ee }}$ activities.

According to Willis, (1996) the task based language comprised three steps in the structural framework of it. The first step was consciousness and also to introduce the students with the subject and task, this was called pre task cycle. The teacher explores the topic with the students, highlights useful words and phrases and helps them understand task instruction and prepare. Here the teacher may use picture, make use of recording or even text as a lead in to a task. The second step was named task cycle, which has three parts in it; those are task, planning and report. In the planning, students do the task; it can be in pairs or small groups. The students are free to experiment without teacher"s intervention, since the teacher monitors from a distance, encourages all attempts at 
communication, and does not correct. Mistakes don "t matter; the students will use whatever target language. In the planning, students prepare to report to the whole class; it can be orally or in written) how they did the task, what they decided or discovered. Students are able to request teacher"s help for language advice, as they will report publicly and they need for sure it will be accurate. Report is the part for the students in groups presenting their result of the discussion, or exchanging the written ones to other groups, even comparing the result to others. The last step was named language focus which has two parts in it; analysis and practice. When analysis is undergoing, the students examine and then discuss specific features of the text or transcript of the recording. They can enter new words, phrases and patterns in vocabulary books. Afterwards teacher will conduct practice of new words, phrases, and patterns occurring in the data, either during or after the analysis. Junior high school students have been introduced to several text genres. Based on Permendikbud no. 68 (2013) those genres are descriptive, procedural, recount, and narrative text.

\section{RESEARCH METHOD}

This study employs descriptive qualitative design which produces descriptive data in the written form from the respondents. This research was conducted at MTS Sunan Kalijaga. This school uses curriculum 2013 for the teaching and learning process. The researcher selected a class in grade 7 which took descritive text based on the consideration that students of grade 7 at junior high school are expected to arrange descriptive text spoken and written, very short and simple, about place, animal/human, and thing, by paying attention to social function, and language features, correctly, appropriately, and contextually (Permendikbud no 68 tahun 2013).

A Teacher and the students who participated in this study were ones whose classroom applying task-based learning in their writing class. The researcher chose a class whose studentse writing scores are low. It aimed to see how TBL was implemented and affects the studentse writing. Data are defined as any information gathered by the researcher from the world of she is studying, particularly researcher seeks the data from the participants, the students and the teacher in the study. The source of data was the results from the process of the implementation of task based learning in the classroom. There two sources of data were used by the researcher. First was the main data source, including the teacher and students ${ }^{\text {ee }}$ verbal behavior in the process of teaching and learning while applying task-based learning in teaching writing, and also the interview result of teacher and students. The researcher posed general, broad questions to participants and allowed them to share their views relatively unconstrained by her perspective. The second data source was the support data; it is called as secondary data source. 
Those were data which researcher collected through the observation in the classroom and also the writing product made by the students during the implementation of task based learning in the classroom. The important part of the research is data collection approach. It determines where the researcher analyzes the data from the participants. In this research the data collection techniques are observation, interview and documents.

\section{Data Analysis Techniques}

After collecting the data, the next step researcher should take is analyzing them. The data obtained by researcher is required to form the answers of the research questions. Inductive analysis was used in this research to analyze the data gained by the researcher before. The data is analyzed from the particular or the detailed data to the general codes and themes (Cresswell, 2012) The data were obtained from observation of the teaching and learning process, the students and teachers activities in the classroom along the process of study and interview ${ }^{\text {ee }}$ result from both students and teacher. The documentation from the observation and the writing product of the students are as supplementary data in developing the report. This research belongs to basic interpretative research in which the data and the result of the data be interpreted by the researcher's point of view (Cresswell, 2012). From the result of data analysis the researcher had them as research findings. The data collected by the researcher was analyzed based on suggestion from (Miles, et.al, 2014); those are data condensation, data display and conclusion drawing/ verification.

\section{FINDING}

The implementation of the task-based learning followed three cycles suggested by (Willis, 1996). The three cycles that teacher had to conduct were pre-task cycle, task cycle and language focus. In the pre-task cycle, students get exposure, and a chance to recall things they know. Teacher helps them in introducing the topic and the task, by asking the students some question related to the topic or read part of a text as a lead in to a task. Teacher asked about the places that students had been there before, their experiences at those places. She also had a text for the first task. Next cycle was called task cycle which students had the most role, they played in almost part of the task cycle; students should discuss to answer some question based on text given and to rearrange some sentences into a meaningful text. After doing the task, each groups planned to report the result of their discussion in written. In reporting the result of their discussion, the representative of the groups will write their answer on the whiteboard. The last cycle was the language focus; this part was teacher who had the responsibility in explaining things related to the linguistic features or the 
structure, though it ${ }^{\text {ee }}$ still required studentse involvement. In this study, the researcher acted as an observer and did not take part in the process of teaching and learning. She observed the activities of teacher and students during the lesson and the method were implemented.

\section{Pre-Task Cycle}

The first step was pre-task cycle; teacher set the students ${ }^{\text {ee }}$ condition and made them well-prepared to follow the lesson. The teacher arranged the preparation and direction to students what they had to do. The teacher mostly dominated this cycle whereas students listened to her carefully. Teacher intended to encourage students in the learning process they would undergo. Teacheres activities can be introducing to the topic and task, using texts and other activities upon those texts. This activities conducted in the pre-task cycle can be elaborated into five activities which had some goals underlying each of them. Those goals must be reached by doing activities in the pre-task cycle were to raise the students ${ }^{\text {ee }}$ consciousness, to introduce students to the subject and task, to explore the topic, to highlight useful words and phrase, to help students understand the task instructions.

\section{Task Cycle}

The second phase in doing task-based learning was task cycle. This cycle consisted two parts, doing the task and reporting it. Mostly in doing the task, students were asked to accomplish the task in groups or in pair. The students were having discussion in groups to accomplish the tasks. The students should communicate in English for every single action they did in the discussion. In this phase, the students played the main roles, whereas teacher only monitored and facilitated them in discussion. It is students centered session; they were free to explore what so ever target language, hence mistakes were not paid attention to, in order to achieve the outcome.

\section{Doing the Task}

In this cycle, after having join with their friends in the same groups, the teacher handed in the pieces of text to them. Then they started to do the task. In this phase there were two parts, first was task and the second was planning and to report. The task was a part when students did discussion in groups. And report was presenting the result of the discussion done by the groups. The students is devided by 6 group. Every group must describe a picture in the task. Than every grup can be disscustion and presentation in front of class. And the task 2 the every group arrange sentence with picture in the task. After that they can present in front of class. 
The teacher appreciated the students since most of the group rearranged those sentences correctly. They firstly translated all those sentences into Bahasa Indonesia and then they put them chronologically. In fact, the students got used to communicate in Bahasa Indonesia and Javanese as their mother tongues. In such manner, it was not easy to have them using English in every single action of discussion. They used English for simple utterances or when the teacher noticed them. Using Javanese made them easier to understand and discuss the task. The teacher walked around the groups and monitored them. The role of the teacher in this phase was less adequate, since the students played the most acts here. Students were free to express their learning process. They ought to use the target language in communication to their teammates. They worked together in a group, discussing their task. In this part, teacher played as monitor and facilitator. The teacher approached some groups she considered calling for her help. As in group 6 , they asked the meaning of some words, and the teacher gave them clues, and one of the member of the group can answer it. She did not give only the answer directly, but guided the students by giving them some clues to find the answer by themselves.

\section{Planning}

After doing the task, groups were planning to report the result of the task. They performed the answer of the assignment by each representative of groups. Two groups had accomplished the task in time, but the other groups needed more time of the given time by the teacher. Those who could fulfill the tasks in limited time deserved to announce the answer on the whiteboard. Teacher monitored the result of the task before the groups performed in front of the class. She only looked at those answer sheet, not to correct those which were un-correct. When she found the answer was not correct, she would ask the group to reassure them.

\section{Reporting}

In reporting, the students did not seem enthusiastic. Most of them feel bashful making mistakes in their result. They should be directed and commanded by the teacher. Students reported their result of discussion by writing it on the whiteboard. They then discussed the answer with the teacher. This role played by the teacher called as advisor, she managed to give the students the knowledge when the students needed to learn the linguistic features and grammatical rules dealt with the task. The students asked about the verbs in simple present as they did not fully remember all of the verbs they need to make a text.

\section{Language Focus}

The next stage was language focus; in which teacher gave explanation about the linguistic features related to the tasks. There were two parts; those were 
Analyze and Practice. In analyzing, students paid attention to her explanation about some difficult words for them. She asked them to look for the meaning of those words in the dictionary, and who es getting it first would be the winner. After having known the meaning of those words, she led the students to pronounce them, it included in the practice. The students repeated after her. There were about ten words pronounced together. Teacher helped the students translating some words they were confused. Moreover teacher explained about the text, its structures and its function.

The implementation of TBL in teaching descriptive text shows that the teacher conducted the task-based learning in three cycle, those were pre-task cycle, task cycle and language focus (Willis \& Willis, 2007) in a sequence. In the first meeting she could implemented those three cycles in two-hour meeting, yet in the second meeting she could not be able to manage the time to have three cycles instead of having two cycles and continuing the last past cycle, language focus, in the later meeting. The incompleteness of having three cycles in one meeting was caused by the lack of time for doing the task. The students felt they needed much time to work on writing descriptive text. Discovering the themes or topics took time to gather the different ideas from the members of a group, then finding the clue words also took more time, and the hardest part was to arrange the sentences from Bahasa Indonesia into the target language, English. It was not easy for them to compose descriptive text from many ideas of the member of the group.

Task-based learning becomes a different way to teach language, in which it helps the students by placing them in a situation like in the real world, a situation where oral communication is essential for them doing a specific task. Task-based learning had the advantage of getting the students to use their skills at their current level, to help develop language through its use. It has the advantage of getting the focus of the students toward achieving a goal where language become a tool, making the use of language a necessity. The students obliged to use the target language in every single action in doing the task (Richards \& Rodgers, 2001). From the observation done in the class, the students mostly spoke their mother tongues, Javanese and Bahasa Indonesia. They did not feel confidence with their English since they only could use simple phrases to speak with their partners.

The main goal of task-based learning was to make students able to communicate using the target language. They should speak in the target language even they made error or mistakes, it is crucial since the aim of using this TBL was to make students active and communicatively learning English. Hence the teacher also used Bahasa collaborated her English in explaining. She felt Bahasa Indonesia will much more help her students understand the lesson than she always 
speaks using English all the time. The students prefer mixing the languages, Javanese, Bahasa Indonesia and simple English. They sometime understand only simple English instructions. When the teacher spoke long sentences in English, they did not catch the meaning of those. Regarding to the task chosen by the teacher for her students, those were classified as ordering and sorting (1) and sharing personal experience (2) (Willis, J., \& Willis, 2007).

The task in the first implementation used reading text in which allowed students to answer some questions and find some verb base, other task was to rearrange sentences. Actually the former task belong to reading, but teacher preferred to use this with the reason that students will be encouraged by seeing the model of text and also answering the text will help them to understand the sample text. The later task was writing a text based on the students ${ }^{\text {ee }}$ experiences. Here the teacher didn't explain the writing technique which she should have been done, such as stated by (Harmer, 2007) that teacher should do give some steps such as planning, drafting, editing, revising, until they come up to the final version. On the contrary, the teacher asked the students in the second implementation to make their own composition using clues from some word they looked for, and developed them in groups. It can be concluded that the implementation of TBL in teaching writing in this study relies on the teacher conducting the three steps and the language used by the students to communicate in doing the tasks. Since the goal of this method were to achieve studentse centeredness and communicative learning.

Students' Writing Ability The researcher analyzed students ${ }^{\text {ee }}$ writing text

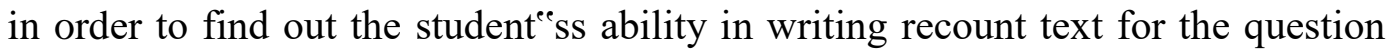
number two. They were analyzed based on the scoring rubric proposed by (O’Malley, \& Pierce, 1996) which has been modified. There are some criteria for the assessment of writing: organization, style, grammar and mechanic.

The group had chosen the right topic which was about holiday. They developed the paragraph so minimalist. Their text consisted of 10 sentences. The following would be the elaboration of the text based on four criteria:

1. The Organization. This criterion reflects how the students put the ideas appropriately and the structures of the text had been placed properly. From the example text above, the students composed two paragraphs. Both of them told about only an event. In the first paragraph, the orientation part used "I" as specific participant. It did not mention the place where the event took place clearly, but the reader will knew it by looking at the title. The sentences mostly used simple present, yet still many errors happened there. As we could see in the first sentence of the first paragraph, "it take..." the word "want" should be changed into "takes." On the second paragraph, it still continued the event in the previous paragraph. Actually, in this place there are many ... the sentence 
should show support sentence.This criteria was about the vocabulary selection to put in the text which was suit and precise. The vocabulary used in the text above was poor. Most of the students were lack of vocabulary and sometime they misused them.

2. Style. The vocabulary chosen by the writers was good enough in describe theirplace. But it was lack of sentence variation, it used simple ones.

3. The Grammar. The rules of the grammar related to the correct use of verb form and tense on sequence, modal articles, preposition and the agreement of subject and predicator. In the text, it was found that many errors were made by the students.

4. The Mechanic. This mechanic criterion was dealt with spelling, punctuation and capitalization used to write in the text. Only few errors made by the students regarding to the capitalization, they used capital letter in the beginning of each sentences.

It showed that students ${ }^{\text {ee }}$ writing results vary for their organization, style, grammar or mechanic. Mostly they had low to average score in most writing criteria. The organization of the text was still not relate wuth other sentence to describe something. In their texts the topic was supported by the ideas which made the text well organized. The topic they chose was about the favorid place was described well enough, it was supported by some ideas developed from the clue words they looked for before. It happened to some groups that the vocabulary they used was very poor and inappropriate. The students used their dictionary to find the English words to put in their text, and they picked the words which they thought have the same meaning with the intended words. In the aspect of grammar, the students were still having trouble to use the tense in the descriptive text. Almost all group got fair for the score of grammar. They had many grammar inaccuracies in their texts, sometimes they forgot to use the present verb in the present sentences. In the aspect of mechanic, the groups had poor score too. They missed the capitalization in writing a person "s name, first letter in a sentence or even.

\section{DISCUSSION}

\section{The Discussion of Students' Writing}

Based on the analysis of students ${ }^{\text {ee }}$ writing descriptive conducted by the researcher, generally the students were low to average in terms of the criteria proposed by (O'Malley, \& Pierce, 1996). They need to be improved more in many aspects of writing, such as style, grammar and vocabulary. As previously stated that the teacher did not apply the steps in writing (drafting, editing, revising and final draft) as suggested by (Harmer, 2007), which was supported by (Brown, 2007), which might make the studentse score low to average. The students had 
achieved the point of understanding what descriptive text was about, as it was seen from their writing result which describe the favorid place using simple present, and its goal is to entertain or to inform the audiences. In term of the generic structures of the text, mostly the group had done well in their composition. They put the orientation first in order to be able to explain who participate, to know information about the place. Still there were many ungrammatical error found, some inaccuracies happened mostly in those texts. There was text written by group 6 which did not use simple present tense. They used simple future tense in their text. The grups something didn't write sentence well. They still make mistake to put some words in the sentence.

\section{The Discussion of the Implementation of Task-based Learning and the Students' Writing Ability}

This part is the sum up of both discussions answering the two research questions mentioned in the earlier chapter. The teacher who implemented the approach which was called the task-based learning had conducted the three steps of TBL based on (Willis, 1996). By doing the appropriate procedure of the TBL, teacher hoped the learning goals were reached by her students at the end of the learning process. The students were expected to be able to communicate in English fluently because in the process of doing the task they should use the target language. They also had to produce a writing product since it was a writing class. The teacher had presented those three steps in the first session, but incomplete steps were showed in the second implementation. This was due to running out of time when the students doing the task, composing the text. The teacher referred to students $^{\text {ee }}$ centered learning as mentioned in Harmer (2001), she only monitored the students to do the activities and using the target language. In fact, the students did not speak using English in their discussion. They spoke only simple utterance whenever the teacher was near them. They were afraid of making mistakes and had no courage using English. The teacher did not apply the writing guidance for her students as stated in (Harmer, 2004). She did not apply to teach writing by planning, drafting, editing and revising. In fact she gave instructions and only walked around monitoring them. The lesson time was the reason she chose not to apply the writing guidance. As a result the students ${ }^{\text {ee }}$ writing product did not show good result, for they had many weaknesses in some aspects, such as grammar, vocabulary and its schematic structures. From the previous points the researcher presented, it led to a decision that the teaching and learning process determine the result. Mostly the successful teaching and learning process using an appropriate approach would produce a good result, whereas the poor teaching and learning process would produce the poor result. 


\section{CONCLUSION}

The task based learning method was aimed to explore the target language used by students. Task-Based learning create opportunities for language learning and skill-development through collaborative knowledgebuilding. Through some tasks the students ought to use the target language for a communicative purpose in order to achieve an outcome. The tasks used in this approach interpret the real world, so students sense factual situation in using the target language. It intends to make the students focus on meaning by processing and accomplishing the tasks given. So the teacher can implement the task based learning in writing descriptive text. Applying The task based learning in writing descriptive text is very important to be applied in the classroom because some researchers in the previous study have suggested to use Task based learning way to improve students' writing ability. Besides that the impleentation of task based learning can be reference to another researcher to improve writing descriptive text in the classroom.

\section{REFERENCE}

Adhe S., H. A. (2013). The Implementation of cmaptools program in teaching descriptive text to junior hight school. Journal of English Language Teachin, 1(March), 2.

Adk, D. P. (2015). The implementation of probem based learninin teaching descriptive text to the eight grade. English and Education Jurnal, 1, 1-7.

Aksu, B. (2015). From descriptive to critical writing: A study on the effectiveness of advanced reading and writing instruction. Procedia - Social and Behavioral Sciences, 199, 620-626. https://doi.org/10.1016/j.sbspro.2015.07.588

Brown, H. D. (2007). Principles of Language Learning and Teaching (5ed). New York: Pearson education Inc.

Butler, Y. G. (2018). The Implementation of Communicative and Task-Based Language Teaching in the Asia-Pacific Region, (2011), 36-57. https://doi.org/10.1017/S0267190511000122

Carless, D. (2007). The suitability of task-based approaches for secondary schools : Perspectives from Hong Kong, 35, 595-608. https://doi.org/10.1016/j.system.2007.09.003

Cresswell, J. W. (2012). Educational Research: Planning, conducting, Conducting and Evaluating Quantitative and Qualitative Research. New Jersey: Pearson Education, Inc.

Hamilton. (1988). Assesment Writting. Canada.

Harmer, J. (2004). How to Teach English. An Introduction to the practice of English Language Teaching. Harlow: Longman.

Harmer, J. (2007). How to teach English. England: Longman.

Heaton, J. B. (1975). Writing English Language Test. London: Longman Group Limited. 
J.Siahaan. (2013). An analysis of students'ability and difficulties in writing descriptive text. Journal of English and Education 2013, 1(2005), 114121.

Kuswoyo, H., \& Hum, M. (2017). Improving Student " s Listening Skill Using Task- Based Approach in EFL Classroom Setting. Advances in Social Science, Education and Humanities Research (ASSEHR), 109(Aecon), 118-123.

Miles, Matthew B., Huberman, A. Micahel, \& Saldana, J. (2014). Qualitative Data Analysis, A Method Sourcebook (3 ed). Washington: Sage. Norland,.

O’Malley, J.M., \& Pierce, L. V. (1996). Authentic Assessment for English Language Learner, Practical Approach for Teacher. Massachusetts: Addison-Wesley.

Oshima, A., \& Hogue, A. (1999). Writing Academic English. Massachusetts: Addison-Wesley Publishing.

Tan, Z. (2016). Benefits and Implementation Challenges of Task-Based Language Teaching in the Chinese EFL Context, (3), 1-8.

Willis, J., \& Willis, D. (2007). Doing Task-Based Teaching. Oxford: Oxford Universitty Press.

Willis, D. (1996). A Framework for Task-Based Learning. Londond: Longman. 